\title{
Life cycle assessment and circular economy in conjunction with treatment methodologies: Presentation and critical comparison between different food industry waste
}

\author{
Antoniadou M 1, Tsarouhas $\mathrm{P}^{2}$ and Varzakas T 3,* \\ ${ }^{1}$ National and Kapodistrian University of Athens, Dental School. \\ ${ }^{2}$ International Hellenic University; Dept. of Supply Chain Management and Logistics. \\ 3 University of the Peloponnese, Dept. Food Science and Technology, School of Agriculture and Food.
}

Publication history: Received on 01 June 2020; revised on 07 June 2020; accepted on 08 June 2020

Article DOI: https://doi.org/10.30574/gscarr.2020.3.3.0048

\begin{abstract}
Life Cycle Assessment (LCA) principles coupled with Circular Economy are well described in this review addressing LCA examples worldwide. Applications of LCA in the food industry are well outlined with examples from the dairy sector and dairy effluents, meat sector (pork), poultry and eggs, coffee, fish canning, animal feed and used cooking oil. LCA is then explained as a management strategy in the food packaging sector. One of the best methodologies for food waste or bio-waste is anaerobic digestion with production of biogas. This review shows the effect of food, energy, water on human life. Hence, we all should be aware that our interventions might affect all these food sectors positively or negatively as well as our lives in general.
\end{abstract}

Keywords: LCA; Circular Economy; Food waste; Anaerobic digestion; landfilling; Incineration

\section{Introduction}

The total production value of global food waste (FW) is estimated at \$1 trillion, increasing to $\$ 2.6$ trillion when social and economic costs are considered [1], while the greenhouse gas (GHG) emissions associated with the FW supply chains account for $6.8 \%$ of global emissions [2,3]. The issue of food waste is thus becoming pertinent in the EU with growing pressures to implement a circular economy [4].

The circular economy principles [5] as well as the waste management hierarchy [6] favour anaerobic digestion (AD) and composting over incineration and landfill. However, their environmental and economic sustainability will vary depending on many factors, including the composition and volume of waste as well as the geographical region where it is generated and treated.

The aim of this review paper then is to compare different sectors of food industry waste bringing up- to- date examples.

\section{LCA examples worldwide}

Oldfield et al. [7] undertook a national life cycle assessment (LCA) study for Ireland, assessing the global warming, eutrophication and acidification potentials of FW treatment via AD, in-vessel composting (IVC), incineration and landfilling, in comparison with waste minimisation. They found that AD had the lowest impacts of the three treatment options for all three environmental indicators, but waste minimisation was the best option when compared to the other three.

\footnotetext{
${ }^{*}$ Corresponding author: Varzakas T
} 
Bernstad and la Cour Jansen (8) also considered the AD, IVC and incineration for a Swedish town, focusing on five impacts: global warming, acidification, ozone depletion, photochemical oxidants formation (summer smog) and nutrient enrichment. Their results suggested the greatest reduction in global warming and photochemical oxidants formation resulted from AD. However, both AD and IVC increased nutrient enrichment and acidification in comparison to incineration. They also reviewed and compared LCA of food waste management systems in other countries [9].

Further, Slorach et al. [10] focused on the UK situation and reported on the life cycle environmental and economic implications of recovering energy and material resources from food waste. Four treatment methods were considered: $\mathrm{AD}$, in-vessel composting, incineration and landfilling. The results showed that per ton of waste treated, AD had the lowest environmental impacts in 13 out of the 19 categories considered in the study, including net-negative global warming potential. The least sustainable option environmentally was in-vessel composting whereas incineration had the lowest life cycle costs $(£ 71 / t)$, and landfilling was the costliest option $(£ 123 / t)$.

To minimize the resource and energy consumption associated with conventional treatment systems, Yeo et al. [11] proposed Smart Food Recycling Bin (S-FRB) technology as a promising decentralized waste treatment facility for application in Hong Kong. S-FRB systems are an efficient onsite organic waste decomposing instrument. This system composts food waste into an energy resource using bio-catalysis, where naturally occurring fermentative microorganisms are embedded in wooden biochips. A large surface area for microorganism to inhabit is provided by the porous structure of the wooden biochips, thus allowing efficient aerobic composting of food waste [12].

This decentralized waste decomposition system has emerged as a possible solution for coping with both landfill capacity and greenhouse gas emissions issues. Yeo et al. [11] utilized LCA to determine the environmental impacts associated with this S-FRB technology and identified environmental hotspots to reduce these impacts. They conducted an on-site pilot-scale study for 2 months at a canteen located at the City University of Hong Kong, which resulted in a 90\% reduction in the mass of food waste treated in the S-FRB system. Based on this pilot-scale study potential environmental impacts were determined by hypothetical scenarios. Examination of the LCAs of these different scenarios demonstrated the potential for further reduction in $\mathrm{CO}_{2}$ equivalent emissions during food waste treatment which are promising results.

\section{Applications of LCA in the food industry}

Different applications of LCA are outlined below with examples from the dairy sector and dairy effluents, meat sector (pork), poultry and eggs, coffee, fish canning, animal feed and used cooking oil.

\subsection{Dairy industry and effluents}

Several works have assessed the environmental impacts of the dairy sector proposing measures for the improvement of the sustainability of the dairy value chains [13-15]. Circularity solutions that can enhance the environmental profile of dairy industry include recovery of bioenergy [16] and use of other renewable energy sources [17], recycling of nutrients [18], recovery of polyhydroxy-alkanoate (PHA) from permeate fraction containing lactose [19] and wastewater treatment and valorisation [20]. So, Kilkis and Kilkis [21], developed a methodological approach for the comparison of different energy and biogas utilization schemes in a dairy farm following CE principles. Also, Stanchev et al. [22] proposed an approach for measuring the environmental performance of the anaerobic treatment of dairy processing effluents based on the CE principles. The potential of AD to close the water, energy and nutrient circular loops was investigated along with the relevant environmental costs and benefits at different levels of the dairy supply chain. The developed methodology was based on Material Flow Analysis (MFA) and LCA applied at three different system levels: the AD plant, the dairy processing facility and the entire dairy supply chain. The approach was demonstrated in a dairy facility coupled with a full-scale AD unit. The results revealed that significant reduction of the overall environmental impact of the processing facility was performed out of excess electricity (426 MWh/annum) and heat (1236 MWh/annum) produced from the AD plant. The recovered energy from AD provided in that case almost $20 \%$ of the energy requirements of the factory reducing the total carbon footprint emissions by $13 \%$ compared to the baseline scenario.

\subsection{Poultry and Eggs sector}

Stakeholders in the Netherlands mentioned specific sustainability challenges related to the following environmental issues: emissions, transport, carbon footprint, livestock feed, manure, and resource use. Based on interviews with 24 stakeholders and supported by scientific literature, de Olde et al. [23] presented an overview of current sustainability challenges and trade-offs in the Dutch egg sector. Moreover, they provided an overview of innovations suggested by stakeholders that can help to address the identified sustainability challenges and described current limitations for the 
implementation of these innovations. Innovations identified were related to animal health and welfare $(\mathrm{n}=13)$, housing systems ( $(n=7)$, economy $(n=8)$, environment $(n=9)$, and organisation $(n=6)$. Stakeholders considered priority, the innovations to reduce particulate matter emissions. In addition, important steps to address current sustainability challenges included the control of poultry red mite, approaches to translate costs for environmental investments to consumers, the closure of manure-feed cycles and improved collaboration in the chain. They revealed the complex interactions between sustainability challenges in the egg sector and gave insights in the different perspectives and considerations stakeholders have. As a result, steps towards sustainable egg production require multi-stakeholder dialogue to find consensus and jointly identify the so-called small wins, i.e. meaningful and feasible steps that can contribute to a more sustainable food system.

Furthermore, Soisontes [24] presented an overview of sustainability concerns in the poultry industry in Germany and Thailand. As Germany is the largest consumer of Dutch eggs, similarities between sustainability concerns can be expected with the previous report. The top 10 of main concerns in Germany included several animal welfare issues including the killing of male layer chicks, de-beaking, stocking density and housing system . Dutch priorities for innovations also recognize the high importance of killing of male layer chicks. Also the role of food retailers , resource use and societal acceptance were important issues that were reported too.

All researchers reported that animal welfare, and especially outdoor access are highly valued by society something that must be kept in mind in such sectors [25-29].

\subsection{Spent coffee grounds}

Coffee is an example of a product, generating $1.88 \mathrm{~kg}$ of spent coffee ground (SCGs) per kg of coffee beans used at the point of consumption [30]. However, SCGs show a potential for valorisation in the bio-economy context. They can be utilised through simple valorisation routes, such as waste-to-energy (e.g. incineration with energy recovery, biomass logs and briquettes) and can be targetted for more complex high-end-value products, such as enzymes and aromas used in the food, cosmetic and pharmaceutical industries [31].

Utilisation of SCGs for production of biodiesel has been reported by some researchers. One of these studies [32] carried out a gate-to-gate techno-economic analysis and estimated the carbon footprint of producing SCGs biodiesel in the conventional two-step transesterification process. Biodiesel had net negative GHG emissions (savings) due to the biogenic carbon sequestered by the SCGs. Tuntiwiwattanapun et al. [33], considered the same process but in comparison with a new one-step esterification method. The authors found that the conventional process had lower energy consumption and climate change impact than the one-step alternative, but higher toxicity-related impacts and land use.

The SCGs valorisation routes are classified by Lange et al. [34] according to the waste hierarchy guidelines [35-36]. The guidelines suggest options for managing waste, aiming to reduce environmental impacts and increase resource efficiency [23]. This has been set in Article 4 of the revised Waste Framework (Directive 2008/98/EC) [35] and is considered a crucial guide for the future transition to a circular economy [37]. The most preferable option in the waste hierarchy is 'preventing waste'; 'prepare for re-use' is the next best alternative to keep the products (resources) longer within the system, when waste is unavoidable. The third option is 'recycling' to achieve conversion of waste into new products or materials. This is followed by recovery of energy and materials from waste [38] named 'other recovery'. The least preferable option is disposal (landfilling).

The waste hierarchy is complemented with a waste-to-energy process guideline to aid the implementation of a circular economy, along with more sustainable production and consumption, [64]. Positioning of waste to-energy technologies across the waste management preferences described in the waste hierarchy is promoted. For recycling, anaerobic digestion is considered the most desirable waste-to-energy alternative, followed by incineration with high-energy recovery and the use of waste to produce solid, gaseous and liquid fuels, as part of the 'other recovery' option.

Finally, the "biomass value cascade" (BVC) [34] has also been proposed to evaluate the value of bioresources recovered from waste, with pharmaceuticals being the most desirable products.

Schmidt-Rivera et al. [39] evaluated the life cycle environmental impacts of utilising SCGs for biodiesel production in comparison with the widely used disposal of SCGs as a waste stream: incineration, landfilling, anaerobic digestion, composting and direct application to land. A cradle to grave approach is presented and the functional unit is defined as 'treatment of 1 tonne of SCGs'. The results showed that the most environmentally sustainable option is incineration of SCGs, with net-negative impacts (savings) in 14 out of 16 categories, followed by direct application of SCGs to land with 11 net-negative impacts. Biodiesel production was the least sustainable option with the highest impacts in 11 categories, 
followed by composting. They also demonstrated that various waste hierarchy and resource valorisation guidelines instead of a life cycle approach could lead to a choice of environmentally inferior SCG utilisation options. Revision of these guidelines should be carried out to ensure their consistency underpinned by life cycle thinking, thus aiding sustainable resource management in a circular economy context.

\subsection{Canned fish industry}

Eco-efficiency should deliver competitive goods and services from an economic point of view and should be linked to a progressive reduction in environmental impacts throughout their life cycle [40]. Laso et al. [41] evaluated the environmental impact of the whole anchovy life cycle [42-44] and determined that the anchovy canning industry generated high amounts of anchovy waste (heads, spines, broken and rest of anchovies) which must be managed [41]. The concept of circular economy is introduced through the valorization of these residues rather than their disposal or incineration.

ISO 14045 standard is expected to shift eco-efficiency toward a life-cycle perspective. The environmental performance of a process or product should be directly related to its economic value [45]. Life Cycle Assessment (LCA) method, standardized through the ISO 14040 and 14044 guidelines, was used to determine the environmental impacts linked to the anchovy life cycle. Life Cycle Costing (LCC), a decision-making tool for calculating the total cost, which is generated over the entire life cycle of products or processes, was also used to quantify the monetary value [46].

Several authors proposed new methodologies to evaluate circular economy by means of a new value-based indicator. Di Maio et al. [47] suggested measuring both resource efficiency and circular economy in terms of the market value of stressed resources and defined circularity as the percentage of the value of stressed resources incorporated in a service or product that is returned after its end-of-life date.

Laso et al. [48] combined Life Cycle Assessment (LCA) and Life Cycle Costing (LCC) and proposed a two-step ecoefficiency methodology assessment for the fish canning industry. Descriptive weighting of environmental indicators (Global Warming Potential, Acidification Potential, Eutrophication Potential and the ReCiPe Single Score Endpoint) coupled with economic (Value Added) indicators was applied to the canned anchovy. LCA-LCC results were coupled to linear programming (LP) tools in order to define a composite eco-efficiency index. A cradle to gate approach was employed to evaluate different origins for anchovy species (South American vs. Cantabrian) and related waste management alternatives (landfill, incineration and valorization). Substantial differences were observed depending on the origin of the fish. Anchovies landed in Cantabria showed a higher value-added score at the expense of larger environmental impacts, mainly due to fuel use intensity. Environmental scores were lowered when fish residues were valorized into marketable products. The environmental and economic benefits of applying CE were also demonstrated.

\subsection{Pork}

Different options for the selection on the functional unit (FU) for pork sector can be found in the literature. In terms of kg live weight [49-52] and kg carcass weight [53-57] mass-based FUs prevail over other choices in most LCA reviewed.

Pork is the main meat variety produced in Europe and the most widely consumed in the world, with 115.5 million tons in 2014 [58]. Moreover, an increase by almost 40\% in its production is expected by 2050 [59]. Spain ranks second (after Germany) within the European pork sector, with $13 \%$ of the total production [60]. Catalan pork production is one of the largest industries in terms of economic revenue of the Spanish pork sector holding about $40 \%$ of the national pork industry and 50\% of pork processing activities [61]. Moreover, Spain exported 1,402,407 tons of pork products in 2012, and Catalonia accounts for $61 \%$ of the total exported volume [61]. Moreover, the pork industry also demands large requirements of water and energy and generates remarkable waste flows [62]. Hence, a change towards more environmentally friendly pork products $[62,63]$ is demanded by stakeholders and consumers.

Furthermore, Noya et al. [64] evaluated the environmental performance of traditional linear pork chain in Catalonia through an LCA approach. The outcomes of the analysis showed that both fodder production and transport activities were identified as the critical stages of the system. Accordingly, alternative schemes based on circular economy principles were proposed and potential environmental credits were estimated. The advantages of moving towards a closing loop production system were presented, and resource efficiency and waste valorisation were the first priorities over final disposal options. In this study, the most critical processes (hotspots) were identified and alternative strategies were defined based on the CE model (cradle-to-cradle approach) to demonstrate the potential benefits on the environmental profile of the pork sector in Catalonia.

\subsection{Animal feed}


In the European Union alone, every year, 6 billion chickens, turkeys and other poultry are slaughtered for meat production and about $25 \%$ of each of these animals is not used for direct human consumption [65]. By rendering these poultry by-products, valuable nutrient sources are obtained, namely poultry byproduct meal (PBM; obtained from heads, bruised meat, bones and viscera) and hydrolyzed feather meal (HF; obtained from feathers and sometimes together with some blood), important sources of protein, antioxidants and fatty acids [66]. Poultry fat (PF) is also obtained from the heads, bruised meat, bones and viscera of poultry. Although PF lacks important n-3 PUFA, such as EPA and DHA, the lower PUFA and higher MUFA content of PF makes it a more stable ingredient to be included in animal feeds than n-3 PUFA rich sources like fish oil [67].

The re-approval of non-ruminant processed land animal proteins in some European animal feeds, namely for fish [68], has initiated the interest in searching for nutrient sources in land animal by-products, which are widely generated and can be valuable biological resources [69]. Silva et al. [70] have employed LCA to quantify the environmental impacts generated in the production of PF and PBM obtained from rendering poultry by-products. However, this study assumed mass allocation (discussing the limitations of using mass allocation without carrying out any sensitivity analysis) to deal with the environmental impacts generated in the poultry production. This leads to a very high attribution of the environmental impacts of the poultry production chain in the production of PF and PBM. Pelletier and Tyedmers [71] have evaluated the LCA of different fish feed formulations, with emphasis on some ingredients used in the formulations, including PBM but not PF.

Campos et al. [72] presented an environmental life cycle assessment of poultry fat (PF), poultry by-product meal (PBM) and steam hydrolyzed feather meal (HF). These ingredients are obtained by rendering poultry byproducts and can be used as valuable feedstuffs for the fish feed industry, displacing traditional fishmeal and fish oil, reducing waste, adding value to by-products of the poultry production and reintroducing them in the economy as high-value products and hence promoting a CE system. A life cycle inventory and model were implemented for the PF, PBM and HF production chains based on data collected from two poultry by-product rendering units: the first producing both PF and PBM, and the second producing only HF. Four environmental impact categories were assessed using the CML [73] life-cycle impact assessment method: global warming (GW), abiotic depletion (AD), acidification (AC) and eutrophication (EUT). The impacts calculated with economic allocation for $1 \mathrm{t}$ of PF, $1 \mathrm{t}$ of PBM and $1 \mathrm{t}$ of HF from poultry byproducts are 666,726 and $597 \mathrm{~kg} \mathrm{CO}_{2}$ eq (GW); 3.8, 4.2 and $3.2 \mathrm{~kg} \mathrm{Sb}$ eq (AD); 4.2, 4.6 and $4.7 \mathrm{~kg} \mathrm{SO}_{2}$ eq (AC); and $1.8,2.0$ and $2.1 \mathrm{~kg} \mathrm{PO}_{4}{ }^{3}-\mathrm{eq}$ (EUT), respectively. The rendering process of by-products is mainly responsible for GW and AD (mainly due to process heat), while the poultry production is the main contributor for AC and EUT. In more detail, a sensitivity analysis of alternative multifunctionality procedures for dealing with poultry by-products was performed, showing that the selected allocation method had a huge influence on the life cycle impacts. Higher impacts were shown when mass allocation was employed instead of economic allocation. Additionally, a sensitivity analysis was conducted on the type of energy used in the rendering process, and distances in poultry by-product transportation to the rendering plants. The results showed that the transportation distance has much less effect whereas the fuel source for process heat or the electricity generation system has a significant influence on the impacts.

\subsection{Used cooking oil (second-generation biodiesel)}

Biodiesel produced from used cooking oil (UCO) or waste cooking oil (WCO) is an advanced biofuel, i.e. secondgeneration since it is obtained from a non-crop feedstock. UCO is currently considered as a cheap biodiesel feedstock [74]. In Greece, some estimate is that the annual available UCO from both restaurants and homes could be as high as $220 \mathrm{kt}$, which, if totally recycled to biodiesel could potentially satisfy up to $9.5 \%$ of the country's current diesel demand [75].

As mentioned above, currently the main route of UCO disposal is the sewage system. Every year vast quantities of UCO are poured into toilets and drains, contaminating water supplies and creating serious problems in wastewater treatment plants [76].

Therefore, it is a prerequisite to recycle UCO to biodiesel, in order to improve Europe's energy supply and security especially under the CE concept [90]. In the EU, around 11.6 Mt/year of UCO-biodiesel are currently produced. In contrast, the capacity of the UCO refinery sector is over $21 \mathrm{Mt} /$ year and this gap could be closed, at least partly, through domestic UCO recycling [77].

The environmental sustainability of second-generation biodiesel (used-cooking-oil) was examined, by Foteinis et al. [78] at industrial-scale, in Greece. The total carbon and environmental footprint per tonne of biodiesel production was $\sim 0.55 \mathrm{t} \mathrm{CO}_{2}$ eq (i.e. $\sim 14 \mathrm{~g} \mathrm{CO} 2 \mathrm{eq} / \mathrm{MJ}$ ) and $58.37 \mathrm{Pt}$, respectively. This is $\sim 40 \%$ lower compared to first-generation biodiesel, an order of magnitude lower than the third-generation (microalgae), since the latter is not a fully-fledged 
technology yet. A three-fold reduction in environmental impacts was observed compared to petrodiesel. Environmental hotspots include energy inputs to drive the process, followed by methanol $\left(\mathrm{CH}_{3} \mathrm{OH}\right)$ and potassium methoxide $\left(\mathrm{CH}_{3} \mathrm{KO}\right)$ consumption. Glycerol $\left(\mathrm{C}_{3} \mathrm{H}_{8} \mathrm{O}_{3}\right)$ and potassium sulfate $\left(\mathrm{K}_{2} \mathrm{SO}_{4}\right)$, both process co-products, resulted into avoided environmental burdens. Furthermore, used-cooking-oil valorisation for biodiesel production can address water pollution concerns from its disposal to the sewage system. The system's environmental sustainability was affected by the total distance and means of transport. Strong incentives for used-cooking-oil recycling, widespread collection systems, and biodiesel supply chain optimization are still pending in Greece, Europe, and worldwide. the secondgeneration biodiesel, which currently represents $15 \%$ of the biodiesel market in Greece, with its overall low environmental footprint and capability to be produced at commercial scales, could act as a stepping-stone in decarbonizing Europe's transport sector and improving supply and energy security.

Table 1 presents major LCA methodologies and parameters analysed by different authors. Table 2 presents examples of food waste material, methodologies and product generation (food or medical use) in different countries.

Table 1 LCA methodologies and parameters analysed

\section{References}

\section{LCA methodologies and parameters analysed}

Cumulative energy demand-Expected energy return on investment

$\begin{array}{ll}\text { Circularity } & \text { Performance Assessment } \\ \text { (Material circularity performance } & \text { critar }\end{array}$ performance indicator)

Eco efficiency (Eco label rating) and Ecoefficiency Index (Linear Programming)

Life Cycle Inventory

Life Cycle Impact Assessment (Impact categories include climate change, terrestrial acidification, freshwater eutrophication, marine eutrophication, water depletion, fossil depletion)ReCiPe Midpoint 1.2 method and SimaPro software v.8.2

Life Cycle Impact AssessmentEnvironmental Impacts of PF, PBM, HF production chains analysing impact categories (global warming, abiotic depletion, acidification and eutrophication)-Sensitivity analysis for calculation of impacts

ReCiPe LCIA method-Endpoint translates environmental impacts into damage categories (human health, ecosystems, resource availability)Actual Life Cycle Inventory Data 
Table 2 Examples of food waste material, methodologies and end product generation (food or medical use) in different countries.

\begin{tabular}{|l|l|l|l|l|l|l|l|}
\hline $\begin{array}{l}\text { Year of } \\
\text { Publication }\end{array}$ & Country & Food waste & $\begin{array}{l}\text { Functional } \\
\text { Unit }\end{array}$ & Method/Treatment & LCA & End product generation \\
\hline 2019 & & & $\begin{array}{l}\text { Smart Food Waste Recycling Bin (S- } \\
\text { FRB) } \\
\text { Comparison with landfilling } \\
\text { Organic Waste Treatment Facilities } \\
\text { (OWTF) }\end{array}$ & $\begin{array}{l}\text { Environmental } \\
\text { impacts of S-FRB }\end{array}$ & $\begin{array}{l}\text { Biofuel } \\
\text { Energy and heat } \\
\text { Biogas }\end{array}$ \\
\hline 2020 & UK & & $\begin{array}{l}\text { Drying, grinding SCGs and in-situ } \\
\text { transesterification (TE) } \\
\text { Defatted SCGs remaining after TE } \\
\text { are incinerated. } \\
\text { Anaerobic digestion } \\
\text { Composting } \\
\text { Incineration } \\
\text { Landfilling }\end{array}$ & $\begin{array}{l}\text { Biodiesel and } \\
\text { production } \\
\text { Heat and electricity } \\
\text { Heat and electricity } \\
\text { Chemical fertilisers } \\
\text { Heat and electricity } \\
\text { Electricity }\end{array}$ \\
\hline 2020 & $\begin{array}{l}\text { Used spent } \\
\text { grounds } \\
\text { (SCGs) }\end{array}$ & $\begin{array}{l}\text { Pretreatment, acid-catalysed } \\
\text { esterification, alkaline-catalysed } \\
\text { esterification, biodiesel refining }\end{array}$ & [31] \\
\hline
\end{tabular}


Antoniadou et al. / GSC Advanced Research and Reviews, 2020, 03(03), 029-050

\begin{tabular}{|c|c|c|c|c|c|c|}
\hline 2019 & UK & Household & $\begin{array}{l} \\
\text { Municipal Solid Waste (MSW) of } \\
\text { which } 1.65 \text { Mt is landfilled and } 2,44 \\
\text { Mt incinerated. } 0.51 \text { Mt collected } \\
\text { separately and } 0.3 \mathrm{Mt} \text { co-mingled } \\
\text { with green waste. Home composted } \\
\text { or animal feed (0.8 Mt). Final } \\
\text { treatment of waste streams } \\
\text { involves In-vessel composting } \\
\text { (IVC) and Anaerobic Digestion } \\
\text { (AD). }\end{array}$ & $\begin{array}{l}\text { AD lowest } \\
\text { environmental } \\
\text { impact including } \\
\text { net-negative } \\
\text { global warming } \\
\text { potential. } \\
\text { Incineration has } \\
\text { the lowest life } \\
\text { cycle costs. } \\
\text { Anaerobic } \\
\text { digestion } \\
\text { would also lead to } \\
\text { savings in } 14 \text { other } \\
\text { impacts compared } \\
\text { to the present } \\
\text { situation, but } \\
\text { would result in a } \\
\text { four times } \\
\text { higher } \\
\text { acidification and } \\
\text { three times } \\
\text { greater emissions } \\
\text { of particulate } \\
\text { matter }\end{array}$ & $\begin{array}{l}\text { Energy and material } \\
\text { resources }\end{array}$ & [10] \\
\hline 2020 & & $\begin{array}{l}\text { Dairy } \\
\text { effluents }\end{array}$ & Anaerobic Digestion & $\begin{array}{l}\text { Material Flow } \\
\text { Analysis (MFA) } \\
\text { and Life Cycle } \\
\text { Assessment (LCA) } \\
\text { applied at three } \\
\text { different system } \\
\text { levels: the AD } \\
\text { plant, the dairy } \\
\text { processing facility, } \\
\text { the entire dairy } \\
\text { supply chain. }\end{array}$ & $\begin{array}{l}\text { Excess electricity (426 } \\
\text { MWh/annum) and heat } \\
(1236 \mathrm{MWh} / \text { annum } \\
\text { Reduction of the total } \\
\text { carbon footprint emissions } \\
\text { by } 13 \%\end{array}$ & $\begin{array}{l}\text { Stanchev } \\
{[22]}\end{array}$ \\
\hline
\end{tabular}


Antoniadou et al. / GSC Advanced Research and Reviews, 2020, 03(03), 029-050

\begin{tabular}{|c|c|c|c|c|c|c|c|}
\hline 2015 & Sweden & $\begin{array}{l}\text { Organic } \\
\text { milk }\end{array}$ & $\begin{array}{l}1 \quad \mathrm{~kg} \text { of } \\
\text { energy- } \\
\text { corrected } \\
\text { milk (ECM). }\end{array}$ & $\begin{array}{l}\text { residual farm resources of biomass. } \\
\text { renewable system based on A) } \\
\text { Biogas based on manure and straw } \\
\text { and B) Biogas based on manure + } \\
\text { RME }\end{array}$ & $\begin{array}{l}\text { consequential life } \\
\text { cycle assessment } \\
\text { (CLCA) }\end{array}$ & Fuel, heat and electricity & $\begin{array}{l}\text { Kimming } \\
{[16]}\end{array}$ \\
\hline 2013 & Italy & Dairy farms & $\begin{array}{l}\text { system } \\
\text { boundaries } \\
\text { at the farm } \\
\text { level, from } \\
\text { cradle to } \\
\text { farm gate. } \\
1 \text { kg of Fat } \\
\text { and Protein } \\
\text { Corrected } \\
\text { Milk (FPCM) }\end{array}$ & $\begin{array}{l}\text { All the flows of materials and } \\
\text { energy associated to milk } \\
\text { production process, including } \\
\text { crops cultivation for fodder } \\
\text { production, were investigated in } 20 \\
\text { dairy commercial farms }\end{array}$ & $\begin{array}{l}\text { calculation of } \\
\text { energy and } \\
\text { environmental } \\
\text { sustainability } \\
\text { indicators (EUI, } \\
\text { CO2-eq) referred } \\
\text { to the functional } \\
\text { units }\end{array}$ & $\begin{array}{l}\text { Fuel and electricity. } \\
\text { The farm activities that } \\
\text { contribute most to the } \\
\text { electricity requirements } \\
\text { were milk cooling, milking } \\
\text { and slurry management, } \\
\text { while feeding management } \\
\text { and crop cultivation were } \\
\text { the greatest diesel fuel } \\
\text { consuming operation and } \\
\text { the largest in terms of } \\
\text { environmental impact of } \\
\text { milk production } 73 \% \text { of } \\
\text { energy C02-eq emissions }\end{array}$ & $\begin{array}{l}\text { Murgia } \\
{[17]}\end{array}$ \\
\hline
\end{tabular}




\begin{tabular}{|c|c|c|c|c|c|c|c|}
\hline 2014 & Netherlands & Dairy farms & $\begin{array}{l}\text { kg fat-and- } \\
\text { protein- } \\
\text { corrected } \\
\text { milk (FPCM) }\end{array}$ & $\begin{array}{l}\text { Economic indicators used were: } \\
\text { farm income per unpaid annual } \\
\text { working unit and the costs to } \\
\text { revenues ratio. Quantification of } \\
\text { the soil content of organic carbon } \\
\text { and phosphorus, and the soil } \\
\text { nitrogen supply. Societal indicators } \\
\text { used were: payments for agri- } \\
\text { environmental measures, grazing } \\
\text { hours and penalties for aberrant } \\
\text { milk composition }\end{array}$ & $\begin{array}{l}\text { sustainability } \\
\text { indicators of nine } \\
\text { Internal Nutrient } \\
\text { Cycle (INC) farms. } \\
\text { Environmental } \\
\text { indicators used } \\
\text { were derived from } \\
\text { a cradle-to-farm- } \\
\text { gate life cycle } \\
\text { assessment: land } \\
\text { occupation (LO), } \\
\text { non-renewable } \\
\text { energy use } \\
\text { (NREU), global } \\
\text { warming potential } \\
\text { (GWP), } \\
\text { acidification } \\
\text { potential (AP) and } \\
\text { eutrophication } \\
\text { potential (EP }\end{array}$ & $\begin{array}{l}\text { Recycling of nutrients. } \\
\text { INC farms had a lower non- } \\
\text { renewable energy use per kg } \\
\text { FPCM, higher soil organic } \\
\text { carbon content and received } \\
\text { higher annual payments for } \\
\text { agri-environmental } \\
\text { measures, whereas } \\
\text { economic and other } \\
\text { environmental, societal } \\
\text { indicators did not differed }\end{array}$ & $\begin{array}{l}\text { Dolman } \\
{[18]}\end{array}$ \\
\hline 2018 & Italy & Whey & & $\begin{array}{l}\text { Waste recycling and biotechnology } \\
\text { (lactose fermentation to produce } \\
\text { PHA) }\end{array}$ & & $\begin{array}{l}\text { Recovery of PHA } \\
\text { (polyhydroxy-alkanoate) } \\
\text { from permeate fraction } \\
\text { containing lactose for food } \\
\text { packaging, shampoos, } \\
\text { razors, diapers, hygiene } \\
\text { products, or cups, dishes } \\
\text { and medical applications } \\
\text { (bone implant materials, } \\
\text { tissue engineering, in-vivo } \\
\text { application as implants, } \\
\text { surgical pins, screws, } \\
\text { meshes and sutures, and as } \\
\text { carrier matrices for } \\
\text { controlled drug release) }\end{array}$ & Rosa [19] \\
\hline
\end{tabular}


Antoniadou et al. / GSC Advanced Research and Reviews, 2020, 03(03), 029-050

\begin{tabular}{|c|c|c|c|c|c|c|c|}
\hline 2018 & $\begin{array}{l}\text { Peru, Chile, } \\
\text { Spain }\end{array}$ & $\begin{array}{l}\text { Canned } \\
\text { anchovy }\end{array}$ & $\begin{array}{l} \\
\\
\text { Qualitative } \\
\text { aspects } \\
\text { (marketing } \\
\text { and the } \\
\text { social } \\
\text { perception } \\
\text { of a high- } \\
\text { quality } \\
\text { product, } \\
\text { such as the } \\
\text { canned } \\
\text { anchovy) } \\
\text { are difficult } \\
\text { to } \\
\text { introduced be } \\
\text { in the } \\
\text { functional } \\
\text { unit }\end{array}$ & $\begin{array}{l}\text { Landfilling } \\
\text { Processing into residual fishmeal } \\
\text { leading to trout aquaculture. } \\
\text { Incineration } \\
\text { Circular economy with valorization } \\
\text { of anchovy residues }\end{array}$ & $\begin{array}{l}\text { Life Cycle } \\
\text { Assessment (LCA) } \\
\text { and Life Cycle } \\
\text { Costing (LCC) } \\
\text { were employed } \\
\text { for a two-step eco- } \\
\text { efficiency } \\
\text { methodology } \\
\text { assessment for the } \\
\text { fish canning } \\
\text { industry. LCA-LCC } \\
\text { results were } \\
\text { coupled to linear } \\
\text { programming (LP) } \\
\text { tools and an } \\
\text { composite eco- } \\
\text { efficiency index } \\
\text { was defined. } \\
\text { Descriptive } \\
\text { weighting of } \\
\text { environmental } \\
\text { (Global Warming } \\
\text { Potential, } \\
\text { Acidification } \\
\text { Potential, } \\
\text { Eutrophication } \\
\text { Potential and the } \\
\text { ReCiPe Single } \\
\text { Score Endpoint) } \\
\text { and economic } \\
\text { (Value Added) } \\
\text { indicators was } \\
\text { applied. }\end{array}$ & $\begin{array}{l}\text { Biogas recovery from } \\
\text { landfilling. } \\
\text { Energy recovery from } \\
\text { incineration. } \\
\text { Anchovies landed in } \\
\text { Cantabria showed a higher } \\
\text { value-added score at the } \\
\text { expense of larger } \\
\text { environmental impacts, } \\
\text { mainly due to fuel use } \\
\text { intensity. Moreover, } \\
\text { environmental scores } \\
\text { were lowered when fish } \\
\text { residues were valorized into } \\
\text { marketable products. The } \\
\text { cradle-to-cradle concept in } \\
\text { the fish canned industry was } \\
\text { introduced. }\end{array}$ & Laso [48] \\
\hline
\end{tabular}


Antoniadou et al. / GSC Advanced Research and Reviews, 2020, 03(03), 029-050

\begin{tabular}{|c|c|c|c|c|c|c|}
\hline 2020 & Netherlands & Egg sector & $\begin{array}{l}\text { Stakeholders mentioned specific } \\
\text { sustainability challenges } \\
\text { related to the following } \\
\text { environmental issues: particulate } \\
\text { matter emissions, transport, } \\
\text { carbon footprint, (environmental } \\
\text { impacts associated with) livestock } \\
\text { feed, manure, and resource use. } \\
\text { Approximately one third of Dutch } \\
\text { poultry manure is in a biomass } \\
\text { incinerated in atalion } \\
\text { installation }\end{array}$ & $\begin{array}{l}\text { A more circular } \\
\text { approach, by } \\
\text { better connecting } \\
\text { feed and manure } \\
\text { cycles on a more } \\
\text { regional level } \\
\text { was suggested by } \\
\text { several } \\
\text { stakeholders to } \\
\text { address } \\
\text { challenges related } \\
\text { to nutrient and } \\
\text { manure surpluses. } \\
\text { Feeding } \\
\text { insects produced } \\
\text { on manure or } \\
\text { leftovers could fit } \\
\text { into a more } \\
\text { circular a } \\
\text { approach and was } \\
\text { considered as a } \\
\text { priority by six } \\
\text { stakeholders. }\end{array}$ & $\begin{array}{l}\text { Solutions to address manure } \\
\text { surplus (i.e. drying poultry } \\
\text { manure or manure } \\
\text { incineration) were } \\
\text { considered as a priority for } \\
\text { their farm by in total } 41 \% \text { of } \\
\text { the farmers }\end{array}$ & $\begin{array}{ll}\text { de } & \text { Olde } \\
{[23]} & \end{array}$ \\
\hline
\end{tabular}




\begin{tabular}{|c|c|c|c|c|c|c|c|}
\hline 2017 & Spain & $\begin{array}{l}\text { Pork value } \\
\text { chain }\end{array}$ & $\begin{array}{l}\text { kg of cut } \\
\text { pork (fresh } \\
\text { or frozen)" }\end{array}$ & 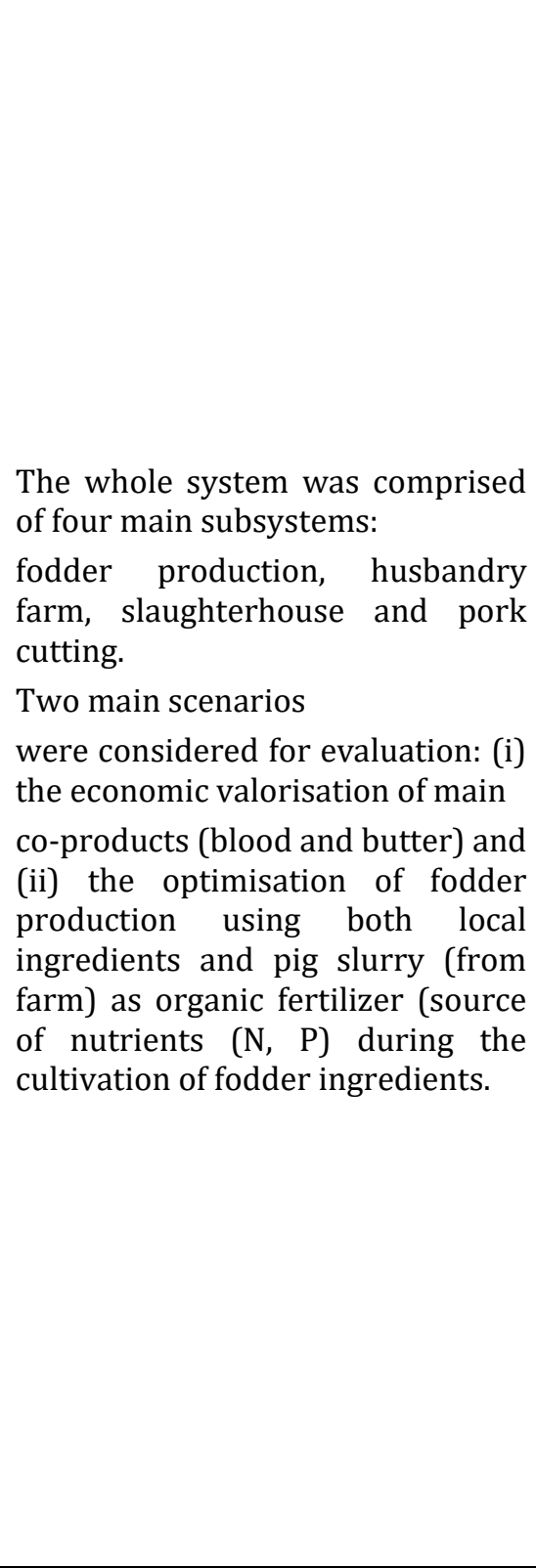 & $\begin{array}{l}\text { A cradle-to-gate } \\
\text { environmental } \\
\text { assessment was } \\
\text { conducted. All } \\
\text { processes } \\
\text { involved in the } \\
\text { pork production } \\
\text { chain including } \\
\text { feed production, } \\
\text { breeding and } \\
\text { fattening pigs at } \\
\text { farm, } \\
\text { slaughterhouse } \\
\text { and cutting stage } \\
\text { (where pork } \\
\text { fresh/frozen pork } \\
\text { is obtained as } \\
\text { output) were } \\
\text { considered. } \\
\text { Climate change } \\
\text { (CC), } \\
\text { terrestrial } \\
\text { acidification (TA), } \\
\text { freshwater } \\
\text { eutrophication } \\
\text { (FE), marine } \\
\text { eutrophication } \\
\text { (ME), water } \\
\text { depletion (WD) } \\
\text { and fossil } \\
\text { depletion } \\
\text { were identified as } \\
\text { the rest } \\
\text { representative } \\
\text { factors. } \\
\text { The productive } \\
\text { system evaluated } \\
\text { responds to }\end{array}$ & $\begin{array}{l}\text { Fodder production } \\
\text { subsystem with locally } \\
\text { cultivated feed mixtures } \\
\text { (wheat, maize, barley) and } \\
\text { also imported ones shows } \\
\text { major influence Most } \\
\text { damaging spot due to the } \\
\text { emissions generated from } \\
\text { the application of mineral } \\
\text { fertilisers for crops } \\
\text { cultivation (especially } \\
\text { wheat and rape meal) } \\
\text { together with combustion } \\
\text { emissions derived from the } \\
\text { use of agricultural } \\
\text { machinery. } \\
\text { Moving towards closingloop } \\
\text { productive systems in } \\
\text { relation to the base situation } \\
\text { (traditional linear system). } \\
\text { Transportation activities } \\
\text { had the greatest } \\
\text { advantageous influence (up } \\
\text { to 13.4\%), a }\end{array}$ & Noya [64] \\
\hline
\end{tabular}




\begin{tabular}{|c|c|c|c|c|c|c|c|}
\hline & & & & & 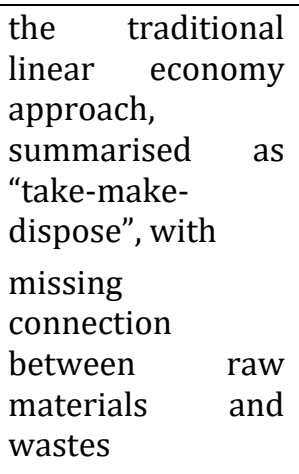 & & \\
\hline 2020 & Portugal & Animal feed & $\begin{array}{l} \\
1 \text { tonne of } \\
\text { each } \\
\text { ingredient } \\
\text { delivered to } \\
\text { the fish feed } \\
\text { producer } \\
\text { gate }\end{array}$ & $\begin{array}{l}\text { poultry fat (PF), poultry by-product } \\
\text { meal (PBM) and steam hydrolyzed } \\
\text { feather meal (HF) obtained by } \\
\text { rendering poultry by-products }\end{array}$ & $\begin{array}{l}\text { Four } \\
\text { environmental } \\
\text { impact categories } \\
\text { were assessed } \\
\text { using the CML life- } \\
\text { cycle impact } \\
\text { assessment } \\
\text { method: global } \\
\text { warming (GW), } \\
\text { abiotic depletion } \\
\text { (AD), acidification } \\
\text { (AC) and } \\
\text { eutrophication } \\
\text { (EUT). } \\
\text { Sensitivity } \\
\text { analysis. }\end{array}$ & $\begin{array}{l}\text { The rendering process of by- } \\
\text { products is mainly } \\
\text { responsible for GW and AD } \\
\text { (mainly due to process } \\
\text { heat), while the poultry } \\
\text { production is the main } \\
\text { contributor for AC and EUT. } \\
\text { Higher impacts when mass } \\
\text { allocation is employed } \\
\text { instead of economic } \\
\text { allocation. The fuel source } \\
\text { for process heat or the } \\
\text { electricity generation } \\
\text { system has a significant } \\
\text { influence on the impacts. } \\
\text { PF, PBM and HF have lower } \\
\text { life cycle impacts } \\
\text { than fish oil or fishmeal }\end{array}$ & $\begin{array}{l}\text { Campos } \\
\text { [72] }\end{array}$ \\
\hline
\end{tabular}




\section{LCA and food packaging}

The importance of the evaluation of costs, benefits, and externalities capturing the variables involved in a product's life cycle are gaining attention both in the literature and with practitioners in the context of CE. In many cases, costs are isolated across the various life cycle stages and addressed in fragmented ways. The literature indicates the importance of developing and implementing life cycle costing methods from the perspective of the product/material flow life cycle. Numerical application of the Product Structure-based Integrated Life Cycle Analysis (PSILA) with the externalities demonstrates the effect of this method on the management of circular businesses. Albuquerque et al. [79] aimed to analyze the benefits of using aluminum packaging in the food sector by combining the life cycle costing (LCC) model and externalities in the CE. The results obtained through the LCC concept and externalities indicate an economic benefit and $\mathrm{CO}_{2}$ reduction. They tried to fill the research gap regarding expenditures and benefits for the analysis of production costs, environmental impacts, and externalities in an integrated manner.

However, methods are currently missing to estimate exposure to chemicals migrating from food packaging into food, which is a major exposure pathway for a variety of potentially toxic chemicals with implications for human health [8083]. Human toxicity characterization in life cycle impact assessment (LCIA) is one distinct strategy for management of human exposure to potentially toxic chemicals with respect to a product system. Emphasis should be given in the difficulty of estimation of the human disease risk related to chemicals in food contact materials, gaps in safety regulations (e.g., lacking toxicity data, and no specific regulations for chemicals in paper and board), and delays between generation of scientific evidence and legislation [84-88]. Other prioritization and screening methods have emerged to manage exposure to chemicals in food packaging materials, for example based on toxicity modeling [89-90, 83].

LCA can thus be explored as a management strategy to address trade-offs between potential toxicity of chemicals in packaging materials and environmental burdens over the packaging life cycle.

Consumer exposure to chemicals in food packaging through the product intake fraction (PiF) metric was responsible for the extension of the LCIA framework for human toxicity Ernstoff et al. [91]. The related exposure pathway was added to LCIA with no other modifications to the existing toxicity characterization framework used by USEtox@, i.e., effect factor derivation. The developed method was applied to a high impact polystyrene (HIPS) container case study with the functional unit of providing $1 \mathrm{~kg}$ of yogurt in single servings.

Various exposure scenarios were considered, including an evidence-based scenario using concentration data and a migration model. Human toxicity impact scores in comparative toxic units (CTUh) for the use stage were evaluated and then compared to human toxicity impact scores from a conventional LCIA methodology. Data allowed toxicity characterization of use stage exposure to only seven chemicals in HIPS out of fourty four identified. The initial concentration of chemicals in food packaging, chemical mass transfer from packaging into food, and relevant toxicity information included data considered. Toxicity characterization demonstrated that the toxicity scores related to consumer exposure to previously estimated concentrations of the seven characterizable chemicals in HIPS were exceeded by the combined CTUh for HIPS material acquisition, manufacturing, and disposal stages by approximately two orders of magnitude. The CTUh associated with consumer exposure became relevant when migration was above $0.1 \%$ of the European regulatory levels. Results emphasized the need to expand the current USEtox method for effect factor derivation (e.g., to consider endocrine disruption, mixture toxicity, background exposure, and thresholds when relevant) and missing data for chemical concentrations in food contact materials.

Alexy et al. [92] identified knowledge gaps on the sustainability and impacts of plastics and presented some recommendations from an expert group organized by the European Commission at the end of 2018. The benefits of plastics in society are unquestionable, but there is an urgent need to better manage their value chain. The recently adopted European Strategy for Plastics stressed the need to tackle the challenges related to plastics with a focus on plastic litter including microplastics. Microplastics have been detected mainly in the marine environment, but also in freshwater, soil and air. Based on today's knowledge they may also be present in food products. Although nanoplastics have not yet been detected, it can be assumed that they are also present in the environment. This emerging issue presents challenges to better understand future research needs and the appropriate immediate actions to be taken to support the necessary societal and policy initiatives. It has become increasingly apparent that in order to achieve sustainable actions and solutions along the entire supply chain, a broad and systematic approach is required. It is recognized that there is pressure for global food and environmental monitoring. However, despite the number of research projects increasing, there is still lack of suitability of validated analytical methods for detection and quantification of micro- and nanoplastics. There is also lack of hazard and fate data for risk assessment. At the same time, it is acknowledged that there is a great complexity in the challenges that need to be tackled before a comprehensive environmental assessment of plastics, covering their entire life cycle, will be possible. 
In order to address major plastic littering and pollution issues, the recently adopted new EU Directive on Single-Use Plastics [93] lays out rules which will ban the use of certain throwaway plastic products for which suitable alternatives exist such as plastic straws, cotton swabs, disposable plastic plates and cutlery by 2021 .

In addition to direct littering of plastics, their degradation due to physical stress from the environment such as abrasion, as in the case of e.g. tires or synthetic clothes being washed and exposure to ultraviolet radiation can trigger the occurrence of very small fragments, the so called microplastics (MPs). These are known as 'secondary' MPs, whereas also 'primary' MPs such as plastic powder, paints and coatings used by industry or microbeads present in cosmetics, detergents and other domestic products used by consumers can be directly released into the environment [94-96].

Although there is no universally agreed definition of MPs (synthetic polymer particles), most studies refer to particles with a diameter size of less than $5 \mathrm{~mm}$; some indicate smaller sizes of $50 \mu \mathrm{m}$ or even $10 \mathrm{~nm}$. The latter belongs to the category of nanoplastics [97-100, 96].

LCA studies have been carried out on recycled PET trays [101-102], extruded PS trays [103-104], (foamed) PLA [103, 104], PP [129] and recycled moulded pulp [103]. Additionally, one study investigated plastic boxes made of PS, PLA and PLA-starch compound [105], while Gallego-Schmid et al. [106-107] analyzed the environmental performance of different food containers made of XPS and PP among others. The study from Belley [129] focused on packaging trays for dry fruits and vegetables.

The EU strategy for plastics, and several national regulations, such as the German Packaging Act, focus on polymeric foam materials as well as hybrid packaging (multilayered plastic). A comparative environmental assessment was conducted by Maga et al [108] to understand the environmental impacts of various tray solutions for meat packaging.

Life cycle assessment (LCA) was applied following the ISO standards 14040/44. The nine packaging solutions investigated were: PS-based trays (extruded polystyrene and extruded polystyrene with five-layered structure containing ethylene vinyl alcohol), PET-based trays (recycled polyethylene terephthalate, with and without polyethylene layer, and amorphous polyethylene terephthalate), polypropylene (PP) and polylactic acid (PLA). Factors such as the production of the tray and the end-of-life stage were included in the LCA study. The results showed that the PS-based trays, especially the mono material solutions made of extruded polystyrene (XPS), exhibit the lowest environmental impact across all 12 impact categories, except for resource depletion. Multilayer products exhibit higher environmental impacts. The LCA also showed that the environmental performance of trays was affected by the end-oflife stage. However, the production of the trays dominated the overall results. Furthermore, the sensitivity analysis illustrated that, XPS based solutions would still outperform the rest from an environmental perspective even if higher recycling rates were carried out in the future.

The European regulations regarding the so-called End of Waste (EoW) criteria should increase the fraction of recycled plastic waste by decreasing landfilling and energy recovery. The application of the EoW defined by the European Union at national level is targeted by early July 2020 [109]. The new approach will be focused on harmonized reporting of input data to recycling; increased targets for plastics (from $22.5 \%$ of 2008 to $50 \%$ by 2025 and 55\% by 2030); new targets for aluminum.

The reported situation of the global plastic waste management system has made the structural crisis of the system clear and has consequently raised the costs of disposal of plastic packaging waste to insurmountable values [110]. Market data [111] clearly shows that it is crucial for Europe as well as USA invest in a strong modification of the industrial network by increasing flexibility and reducing the cost of chain.

Plastic waste disposal requires to avoid meaningless policy responses against the plastic materials putting into practice the criteria of circular economy [112]. A wide range of goods in all the sectors of our life: packaging, construction, biomedicals, etc is included in the world of plastic materials. An industrial network characterized by reliability, flexibility, sustainability, utility in the industrial cycle and ability to provide useful products to the market is the answer to the plastic waste disposal. The traditional processes including recycling and energy recovery fulfil only a part of these conditions. They need to be assessed in correlation to their real effect on the circular economy such as the uses of the obtained products in the anthroposphere's life cycle, the burdens generated by the processes itself, etc. Mastellone [112] discussed and assessed possible processes based on thermochemical exploitation of products obtained by plastics among those that can be more sustainable if compared with the traditional ones, in a real circular economy perspective. The results showed that it is possible to transform an expensive and non-resolving plastic waste management system in an industrial network. The results showed that an integration between the present system with the production of petrochemical products, including oil/gasoline/syngas/, strongly improves the economic performance of the overall 
waste system, with larger savings of not-renewable resources, a limited greenhouse burden, a release in the market of valuable products instead of poor quality materials and the minimization of waste destined to be landfilled.

\section{Conclusion}

Every food sector has its own best ways of disposition. Regarding anaerobic digestion this is the best option involved in food waste. The three Rs' philosophy (Reduce, Reuse, Recycle) need to be employed all along the sectors outlined i.e. food, environmental.

More effective plastic waste management, needs to be supported by implementation of stricter legislation or revision of the laws to improve the efficiency and reduce the amount of plastic waste and encouragement of the implementation of a CE in plastic value chains. This needs to take place in all the food sectors outlined here.

\section{Compliance with ethical standards}

\section{Acknowledgments}

No specific acknowledgments are declared.

\section{Disclosure of conflict of interest}

The authors declare no conflict of interest and state that they have equally contributed to the writing and editing of this manuscript.

\section{References}

[1] FAO, Food and Agriculture Organisation of the United Nations. (2014). Food wastage footprint - full-cost accounting - final report.

[2] FAO, Food and Agriculture Organisation of the United Nations - FAO. (2015). Food wastage footprint \& climate change.

[3] The World Bank. (2016). Total greenhouse gas emissions (kt of CO2 equivalent).

[4] EC. (2015). Closing the Loop-An EU Action Plan for the Circular Economy. Communication From the Commission to the European Parliament, the Council, the European Economic and Social Committee and the Committee of the Regions, $\operatorname{COM}(2015), 614$ (2). European Commission (EC), Brussels.

[5] EMF. (2015). Delivering the Circular Economy - A Toolkit for Policy Makers. Ellen MacArthur Foundation (EMF), Isle of Wight.

[6] DEFRA. (2018). Food and drink waste hierarchy: deal with surplus and waste.

[7] Oldfield TL, White E and Holden NM. (2016). An environmental analysis of options for utilising wasted food and food residue. Journal of Environmental Management, 183 (3), 826-835.

[8] Bernstad A and la Cour Jansen J. (2011). A life cycle approach to the management of household food waste - a Swedish full-scale case study. Waste Management, 31(8), 1879-1896.

[9] Bernstad A and la Cour Jansen J. (2012). Review of comparative LCAs of food waste management systems current status and potential improvements. Waste Management, 32 (12), 2439-2455.

[10] Slorach PC, Jeswani HK, Cuéllar-Franca R and Azapagic. (2019). A. Environmental and economic implications of recovering resources from food waste in a circular economy. Science Total Environment, 693, 133516.

[11] Yeo J, Chopra SS, Zhang L and An AK. (2019). Life cycle assessment (LCA) of food waste treatment in Hong Kong: On-site fermentation methodology. Journal of Environmental Management, 240, 343-351.

[12] Oh J and Lee H. (2015). Experimental evaluation and resident's assessment of zero food waste system in multifamily housing estates. Journal of Korean Society Environmental Engineering, 37, 674-681.

[13] Battini F, Agostini A, Boulamanti AK, Giuntoli J and Amaducci S. (2014). Mitigating the environmental impacts of milk production via anaerobic digestion of manure: case study of a dairy farm in the Po Valley. Science Total Environment, 481, 196-208. 
[14] Hospido A, Moreira MT and Feijoo G. (2003). Simplified life cycle assessment of Galician milk production. International Dairy Journal, 13, 783-796.

[15] Roy P, Nei D, Orikasa T, Xu Q, Okadome H, Nakamura N and Shiina T. (2009). A review of life cycle assessment (LCA) on some food products. Journal of Food Engineering, 90, 1-10.

[16] Kimming M, Sundberg C, Nordberg Å, Baky A, Bernesson S and Hansson PA. (2015). Replacing fossil energy for organic milk production e potential biomass sources and greenhouse gas emission reductions. Journal of Cleaner Production, 106, 400-407.

[17] Murgia L, Todde G, Caria M and Pazzona A. (2013). A partial life cycle assessment approach to evaluate the energy intensity and related greenhouse gas emission in dairy farms. Journal of Agricultural Engineering, 44.

[18] Dolman MA, Sonneveld MPW, Mollenhorst H and De Boer IJM. (2014). Benchmarking the economic, environmental and societal performance of Dutch dairy farms aiming at internal recycling of nutrients. Journal of Cleaner Production, 73, 245-252.

[19] Rosa F. (2018). Waste Generated by Food Industry and Reuse in A Circular Economy Approach: the Whey Processing. Concepts of Dairy \& Veterinary Sciences.

[20] Gottschall N, Boutin C, Crolla A, Kinsley C and Champagne P. (2007). The role of plants in the removal of nutrients at a constructed wetland treating agricultural (dairy) wastewater, Ontario, Canada. Ecological Engineering, 29, 154-163.

[21] Kılkıs S and Kılkıs B. (2017). Integrated circular economy and education model to address aspects of an energywater-food nexus in a dairy facility and local contexts. Journal of Cleaner Production, 167, 1084-1098.

[22] Stanchev P, Vasilaki V, Egas D, Colon J, Ponsa S and Katsou E. (2020). Multilevel environmental assessment of the anaerobic treatment of dairy processing effluents in the context of circular economy. Journal of Cleaner Production, 261, 121139.

[23] De Olde EM, van der Linden A, olde Bolhaar LD and de Boer IJM. (2020). Sustainability challenges and innovations in the Dutch egg sector. Journal of Cleaner Production, 258, 120974.

[24] Soisontes S. (2017). Concerns about sustainability in the poultry industry: a comparative Delphi study in Germany and Thailand. World Poultry Science Journal, 73 (4), 886-903.

[25] Bos JM, van den, Belt H and Feindt PH. (2018). Animal welfare, consumer welfare, and competition law: the Dutch debate on the Chicken of Tomorrow. Animal Frontiers, 8(1), 20-26.

[26] Busch G, Gauly M and Spiller A. (2018). Opinion paper: what needs to be changed for successful future livestock farming in Europe? Animal, 12(10), 1999-2001.

[27] Janssen M, Rodiger M and Hamm U. (2016). Labels for animal husbandry systems meet consumer preferences: results from a meta-analysis of consumer studies. Journal of Agricultural Environmental Ethics, 29(6), 10711100.

[28] Van Loo EJ, Caputo V, Nayga RM and Verbeke W. (2014). Consumers' valuation of sustainability labels on meat. Food Policy, 49, 137-150.

[29] Zakowska-Biemans S and Tekien A. (2017). Free range, organic? Polish consumers preferences regarding information on farming system and nutritional enhancement of eggs: a discrete choice-based experiment. Sustainability, 9(11).

[30] Cameron A and O'Malley S. (2016). Coffee Ground Recovery Program Summary Report. Planet Ark.

[31] Karmee SK. (2017).A spent coffee grounds based biorefinery for the production of biofuels, biopolymers, antioxidants and biocomposites. Waste Management (Oxford), 72, 240-254.

[32] Kookos IK. (2018). Techno-economic and environmental assessment of a process for biodiesel production from spent coffee grounds (SCGs). Resources Conservation Recycling, 134, 156-164.

[33] Tuntiwiwattanapun N, Monono E, Wiesenborn D and Tongcumpou C. (2017). In-situ transesterification process for biodiesel production using spent coffee grounds from the instant coffee industry. Industrial Crops Production, 102, 23-31.

[34] Lange L, Bech L, Busk PK, Grell MN, Huang Y, Lange M, Linde T, Pilgaard B, Roth D and Tong X. (2012).The importance of fungi and of mycology for a global development of the bioeconomy. IMA Fungus Global Mycology Journal, 3, 87-92. 
[35] EC. (2008). Directive 2008/98/EC of the European Parliament and of the Council of 19 November 2008 on waste and repealing certain Directives, OJ L 312, 22.11.2008, 3.

[36] DEFRA. (2011). Guidance on Applying the Waste Hierarchy. Royal Academy of Engineering.

[37] EC. (2017a).The role of waste-to-energy in the circular economy. COM (2017) 34 final.

[38] EC. (2012). Guidance on the interpretation of key provisions of Directive 2008/98/EC on waste.

[39] Schmidt Rivera XC, Gallego-Schmid A, Najdanovic-Visak V and Azapagic A. (2020). Life cycle environmental sustainability of valorisation routes for spent coffee grounds. From waste to resources Resources Conservation and Recycling, 157, 104751.

[40] Lorenzo-Toja Y, Vázquez-Rowe I, Amores MJ, Termes-Rifé M, Marín-Navarro D, Moreira MT and Feijoo G. (2016). Benchmarking wastewater treatment plants under an eco-efficiency perspective. Science Total Environment, 566-567, 468-479.

[41] Laso J, Margallo M, Celaya J, Fullana P, Bala A, Gazulla C, Irabien A and Aldaco R. (2016a). Waste management under a life cycle approach as a tool for a circular economy in the canned anchovy industry. Waste Management Research, 34(8), 724-733.

[42] Laso J, Margallo M, Fullana P, Bala A, Gazulla C, Irabien A and Aldaco R. (2016b). Introducing life cycle thinking to define best available techniques for products: application to the anchovy canning industry. Journal of Cleaner Production, 155(1), 139-150.

[43] Laso J, Margallo M, Fullana P, Bala A, Gazulla C, Irabien A and Aldaco R. (2017). When product diversification influences life cycle impact assessment: a case study of canned anchovy. Science Total Environment, 581-582, 629-639.

[44] Laso J, Vázquez-Rowe I, Margallo M, Crujeiras RM, Irabien A and Aldaco R. (2018a). Life cycle assessment of European anchovy (Engraulis encrasicolus) landed by purse seine vessels in northern Spain. International Journal of Life Cycle Assessment, 23, 1107-1125.

[45] ISO 14045. (2012). Environmental Management - Eco-efficiency Assessment of Product Systems-Principles, Requirements and Guidelines.

[46] Yang D, Fan L, Shi F, Liu Q and Wang Y. (2017). Comparative study of cement manufacturing with different strength grades using the coupled LCA and partial LCC methods-A case study in China. Resources. Conservation and Recycling, 119, 60-68.

[47] Di Maio F, Rem PC, Baldé K and Polder M. (2017). Measuring resource efficiency and circular economy: a market value approach. Resources Conservation and Recycling, 122, 163-171.

[48] Laso J, García-Herrero I, Margallo M, Vázquez-Rowe I, Fullana P, Bala A, Gazulla C, Irabien Á and Aldaco R. (2018b). Finding an economic and environmental balance in value chains based on circular economy thinking: An eco-efficiency methodology applied to the fish canning industry. Resources Conservation Recycling, 133, 428437.

[49] Dolman MA, Vrolijk HCJ and de Boer IJM. (2012). Exploring variation in economic, environmental and societal performance among Dutch fattening pig farms. Livestock Science, 149 (1-2), 143-154.

[50] Dourmad JY, Ryschawy J, Trousson T, Bonneau M, González J, Houwers HWJ, Hviid M, Zimmer C, Nguyen TLT and Morgensen L. (2014). Evaluating environmental impacts of contrasting pig farming systems with the life cycle assessment. Animal, 8, 2027-2037.

[51] Halberg N, Hermansen JE, Kristensen IS, Eriksen J, Tvedegaard N and Petersen BM. (2010). Impact of organic pig production systems on $\mathrm{CO}_{2}$ emission, $\mathrm{C}$ sequestration and nitrate pollution. Agronomic Sustainability Deviation, 30(4), 721-731.

[52] Pelletier N, Lammers P, Stender D and Pirog R. (2010). Life cycle assessment of high- and low-profitability commodity and deep-bedded niche swine production systems in the upper Midwestern United States Agricultural Systems, 103(9), 599-608.

[53] Devers L, Kleynhans TE and Mathijs E. (2012). Comparative life cycle assessment of Flemish andWestern Cape pork production. Agrekon, 51, 105-128.

[54] Jacobsen R, Vandermeulen V, Van Huylenbroeck G and Gellynck X. (2013). Carbon footprint of pigmeat in Flanders. International Journal of Agricultural Sustainability, 12, 54-70. 
[55] Nguyen TLT, Hermansen JE and Mogensen L. (2011). Environmental Assessment of Danish Pork. Internal Report. Faculty of Agricultural Science, Aarhus University.

[56] Reckmann K, Traulsen I and Krieter J. (2013). Life cycle assessment of pork production: a data inventory for the case of Germany. Livestock Science, 157, 586-596.

[57] Wiedemann S, McGahan E, Grist S and Grant T. (2010). Environmental Assessment of Two Pork Supply Chains Using Life Cycle Assessment. Rural Industries Research and Development Corporation. Australian Government, Australia.

[58] FAO. World Livestock. (2011). Livestock in Food Security. Food and Agriculture Organization of the United Nations, 2011, Rome.

[59] FAO. FAO's Animal Production and Health Division: Meat \& Meat Products (online). Food and Agriculture Organization of the United Nations, Rome (2014).

[60] FAOSTAT. (2013). FAOSTAT Database. Food and Agriculture Organization of the United Nations.

[61] Observatori del Porcí. (2013). Informe anual de l'observatori del porcí. Department d'Agricultura, Ramadería, Pesta, Alimentació i Medi Natural (DAAM). Generalitat de Catalunya ISBN: 978-84-697-1467-6.

[62] PRTR. (2014). Registro Estatal de Emisiones y Fuentes Contaminantes. Ministerios de Agricultura, Alimentación y Medio Ambiente, Spain.

[63] Notarnicola B, Hyashi K, Curran MA and Huisingh D. (2012). Progress in working towards a more sustainable agri-food industry. Journal of Cleaner Production, 28, 1-8.

[64] Noya I, Aldea X, González-García S, Gasol CM, Moreira MT, Amores MJ, Marín D and Boschmonart-Rives J. (2017). Environmental assessment of the entire pork value chain in Catalonia - A strategy to work towards Circular Economy. Science of the Total Environment, 589, 122-129.

[65] EPFRA. (2016). Rendering in numbers.

[66] Lasekan A, Abu Bakar F and Hashim D. (2013). Potential of chicken by-products as sources of useful biological resources. Waste Management, 33(3), 552-565.

[67] Watanabe T. (1989). Nutritive value of animal and plant lipid sources for fish. In: Shiau SY. Marine (Ed.), Progress in Fish Nutrition. Proc. Fish Nutrition Symp, 9, 151-166.

[68] European Commission. (2013). Commission Regulation (EU) No 56/2013 of 16 January 2013 amending Annexes I and IV to Regulation (EC) No 999/2001 of the European Parliament and of the Council laying down rules for the prevention, control and eradication of certain transmissible spongiform encephalopathies. Off. J.Eur. Union 30, $33-43$.

[69] NRC. (2011). Nutrient Requirements of Fish and Shrimp. The National Academy Press, Washington DC, USA.

[70] Silva CB, Valente LM, Matos E, Brandao M and Neto B. (2018). Life cycle assessment of aquafeed ingredients. International Journal of Life Cycle Assessment, 23(5), 995-1017.

[71] Pelletier N and Tyedmers P. (2007). Feeding farmed salmon: is organic better? Aquaculture, 272(1-4), 399-416.

[72] Campos IL, Pinheiro Valente M, Matos E, Marques P and Freire F. (2020). Life-cycle assessment of animal feed ingredients: Poultry fat, poultry by-product meal and hydrolyzed feather meal. Journal of Cleaner Production, 252,119845 .

[73] Guinee J, Gorree M, Heijungs R, Huppes G, Kleijn R, de Koning A, Oers L, Wegener Sleeswijk A, Suh S, Udo de Haes H, Bruijn H, van Duin R and Huijbregts M. (2002). Handbook on LCA, Operational Guide to the ISO Standards.

[74] Phillips D. (2019). In: Tomkinson J. (Ed.), Implications of Imported Used Cooking Oil (UCO) as a Biodiesel Feedstock, NNFCC Ltd, York, UK, 24.

[75] European Commission. (2013). In: L. Programme (Ed.), BIOFUELS-2G Demonstration of a Sustainable \& Effective 2nd Generation Biofuels Application in an Urban Environment, 64.

[76] Cordero-Ravelo V and Schallenberg-Rodriguez J. (2018). Biodiesel production as a solution to waste cooking oil (WCO) disposal. Will any type of WCO do for a transesterification process? A quality assessment. Journal of Environmental Management, 228, 117-129.

[77] Loizides MI, Loizidou XI, Orthodoxou DL and Petsa D. (2019). Circular bioeconomy in action: collection and recycling of domestic used cooking oil through a social, reverse logistics system. Recycling, 4(2), 16. 
[78] Foteinis S, Chatzisymeon E, Litinas A and Tsoutsos T.(2020). Used-cooking-oil biodiesel: Life cycle assessment and comparison with first- and third-generation biofuel. Renewable Energy, 153, 588-600.

[79] Albuquerque LMT, Mattos CA, Scur G and Kissimoto K. (2019). Life cycle costing and externalities to analyze circular economy strategy: Comparison between aluminum packaging and tinplate. Journal of Cleaner Production, 234, 477-486.

[80] Poças F and Hogg TA. (2007). Exposure assessment of chemicals from packaging materials in foods: a review. Trends Food Science and Technology, 18, 219-230.

[81] Muncke J. (2011). Endocrine disrupting chemicals and other substances of concern in food contact materials: an updated review of exposure, effect and risk assessment. Journal of Steroid Biochemistry Molecular Biology, 127 (1-2), 118-127.

[82] FDA. (2015a). CEDI Database.

[83] Karmaus AL, Filer DL, Martin MT and Houck KA. (2016). Evaluation of food-relevant chemicals in the ToxCast high-throughput screening program. Food Chemical Toxicology, 92, 188-196.

[84] Biedermann M and Grob K. (2013). Assurance of safety of recycled paperboard for food packaging through comprehensive analysis of potential migrants is unrealistic. Journal of Chromatography A, 1293, 107-119.

[85] Maffini MV, Alger HM, Olson ED and Neltner TG. (2013). Looking back to look forward: a review of FDA's food additives safety assessment and recommendations for modernizing its program. Comprehensive Reviews Food Science and Food Safety, 12, 439-453.

[86] Neltner TG, Alger HM, Leonard JE and Maffini MV. (2013). Data gaps in toxicity testing of chemicals allowed in food in the United States. Reproductive Toxicology, 42, 85-94.

[87] Kortenkamp A. (2014). Low dose mixture effects of endocrine disrupters and their implications for regulatory thresholds in chemical risk assessment. Current Opinion in Pharmacology, 19, 105-111.

[88] EFSA. (2017). Non-plastic food contact materials European Food Safety Authority.

[89] Oldring PKT, O’Mahony C, Dixon J, Vints M, Mehegan J, Dequatre C and Castle L. (2014). Development of a new modelling tool (FACET) to assess exposure to chemical migrants from food packaging. Food Additives Contaminants Part Chemical Analytical Control Expo Risk Assessment, 31, 444-465.

[90] Biryol D, Phillips K, Nicolas C, et al (2015). High-throughput dietary exposure predictions for chemical migrants from food packaging materials. ISES Annual Meeting, Henderson, NV, Henderson, NV, October, 18 - 23.

[91] Ernstoff A, Niero M, Muncke J, Trier X, Rosenbaum RK, Hauschild M and Fantke P. (2019). Challenges of including human exposure to chemicals in food packaging as a new exposure pathway in life cycle impact assessment. The International Journal of Life Cycle Assessment, 24, 543-552.

[92] Alexy P, Anklam E, Emans T, Furfari A, Galgani F, Hanke G, Koelmans A, Pant R, Saveyn H and Sokull Kluettgen B. (2020). Managing the analytical challenges related to micro- and nanoplastics in the environment and food: filling the knowledge gaps. Food Additives and Contaminants Part A, 37(1), 1-10.

[93] European Commission. (2018b). Proposal for a directive of the European parliament and of the council on the reduction of the impact of certain plastic products on the environment, COM (2018) 340 final.

[94] Cole M, Lindeque P, Halsband C and Galloway TS. (2011). Microplastics as contaminants in the marine environment: A review. Marine Pollution Bulletin, 62, 2588-2597.

[95] Boucher J and Friot D. (2017). Primary microplastics in the oceans: a global evaluation of sources. Gland (Switzerland): IUCN, 43.

[96] [GESAMP] Group of Experts on the Scientific Aspects of Marine Environmental Protection. (2019). Joint group of experts on the scientific aspects of marine environmental protection: sources, fates and effects of microplastics in the marine environment: part two of a global assessment (Kershaw PJ, Rochman CM, Eds.), GESAMP reports and studies number, 93, 220.

[97] Law KL and Johnson RC. (2014). Microplastics in the seas. Science, 80, 144-145.

[98] Verschoor AJ. (2015). Towards a definition of microplastics -considerations for the specification of physicochemical properties, RIVM Letter Report, 0116. 
[99] [SAPEA] Science Advice for Policy by European Academies. (2019). A scientific perspective on microplastics in nature and society, SAPEA Report.

[100] Hartmann NB, Hueffer T, Thompson RC, Hasselloev M, Verschoor A, Daugaard AE, Rist AS, Karlsson T, Brennholt $\mathrm{N}$, Cole M, et al. (2019). Are we speaking the same language? Recommendations for a definition and categorization framework for plastic debris. Environmental Science and Technology, 53, 1039-1047.

[101] Wikström F, Williams H and Venkatesh G. (2016). The influence of packaging attributes on recycling and food waste behaviour-An environmental comparison of two packaging alternatives. Journal of Cleaner Production, 137, 895-902.

[102] Belley, C. (2011). Comparative Life Cycle Assessment Report of Food Packaging Products.

[103] Ingrao C, Lo Giudice A, Bacenetti J, Mousavi Khaneghah A, Sant'Ana AS, Rana R and Siracusa V. (2015). Foamy polystyrene trays for fresh-meat packaging: Life-Cycle inventory data collection and environmental impact assessment. Food Research International, 76, 418-426.

[104] Ingrao C, Gigli M and Siracusa V. (2017). An attributional Life Cycle Assessment application experience to highlight environmental hotspots in the production of foamy polylactic acid trays for fresh-food packaging usage. Journal of Cleaner Production, 150, 93-103.

[105] Suwanmanee U, Varabuntoonvit V, Chaiwutthinan P, Tajan M, Mungcharoen T and Leejarkpai T. (2013). Life cycle assessment of single use thermoform boxes made from polystyrene (PS), polylactic acid, (PLA), and PLA/starch: Cradle to consumer gate. International Journal of Life Cycle Assessment, 18, 401-417.

[106] Gallego-Schmid A, Mendoza JMF and Azapagic A. (2019). Environmental impacts of takeaway food containers. Journal of Cleaner Production, 211, 417-427.

[107] Gallego-Schmid A, Mendoza JMF and Azapagic A. (2018). Improving the environmental sustainability of reusable food containers in Europe. Science Total Environment, 628-629, 979-989.

[108] Maga D, Hiebel M and Aryan VA. (2019). Comparative Life Cycle Assessment of Meat Trays. Made of Various Packaging Materials. Sustainability, 11, 5324.

[109] Langendorff J. (2018). More and better recycling for a circular economy - the EU in action. European Recycling Conference, Berlin.

[110] CEA. (2019). Plastic waste disposal fee (private communication).

[111] WRAP. (2019). Market Snapshot.

[112] Mastellone ML. (2020). Technical description and performance evaluation of different packaging plastic waste management's systems in a circular economy perspective. Science Total Environment, 718, 137233.

\section{How to cite this article}

Antoniadou M, Tsarouhas P and Varzakas T. (2020). Life cycle assessment and circular economy in conjunction with treatment methodologies: Presentation and critical comparison between different food industry waste. GSC Advanced Research and Reviews, 3(3), 29-50. 